\title{
Relationships between seagrass biodiversity and infaunal communities: implications for studies of biodiversity effects
}

\author{
Paul J. Somerfield ${ }^{1, *}$, Supaporn Yodnarasri ${ }^{2}$, Chittima Aryuthaka ${ }^{2}$ \\ ${ }^{1}$ Plymouth Marine Laboratory, Prospect Place, Plymouth PL1 3DH, United Kingdom \\ ${ }^{2}$ Department of Marine Science, Faculty of Fisheries, Kasetsart University, Bang Khen, Bangkok 10900, Thailand
}

\begin{abstract}
Controlled experiments to elucidate links between ecosystem functioning and biodiversity have produced differing results. We investigate links between the species diversity in multispecies tropical seagrass beds in Thailand and the abundance, diversity and community structure of free-living nematodes within the beds. No relationship was found between seagrass diversity and nematode species richness or abundance, but a posteriori power analyses demonstrate that our sampling design had little prospect of detecting such relationships against a background of naturally occurring variability. We conclude that in a variable world biodiversity effects may be difficult to detect, even if they are large. Multivariate analyses show that there are relationships between seagrass diversity and the community structure of free-living nematodes, with different nematode assemblages occurring in patches of seagrasses with different numbers of seagrass species. We therefore conclude that biodiversity effects do exist in the real world. Different mixtures of seagrass species alter environmental conditions and food availability within the sediment through a range of processes (ranging from sediment trapping to interspecific differences in photosynthate production) which in turn affect differences in nematode community structure directly or through indirect pathways.
\end{abstract}

KEY WORDS: Biodiversity $\cdot$ Ecosystem functioning $\cdot$ Power analysis $\cdot$ Experiments $\cdot$ Seagrasses Nematodes $\cdot$ Community structure $\cdot$ Indo-West Pacific

\section{INTRODUCTION}

Concern about the ecological consequences of ongoing and future losses of biodiversity, caused by the increasing impact of human activities on ecosystems, has led to the relationship between biodiversity and the functioning of ecosystems emerging as a major scientific issue (Heip et al. 1998, Loreau 2000). The belief that a reduction of biodiversity leads to a loss of ecosystem functions and the services that ecosystems provide has raised concerns about the preservation of biological diversity (Duarte 2000). Experimental tests of the links between biodiversity and ecosystem functions

*E-mail: pjso@pml.ac.uk typically focus on the relationships between measurable functions and species richness, and although such experiments have been performed in terrestrial (Naeem et al. 1994, Tilman \& Downing 1994, Tilman et al. 1996 inter alia), freshwater (Engelhardt \& Ritchie 2001) and marine (Emmerson et al. 2001) systems with varying degrees of success, no predictable link between species diversity and any ecosystem function has been conclusively demonstrated (Cardinale et al. 2000). Nor is there a clear consensus about the nature of such links (Schläpfer et al. 1999), even though it is widely believed that such links are strong in marine systems (Heip et al. 1998). Even less progress has been made towards relating a specific biodiversity/function relationship to a particular conservation problem, although it is considered necessary to demonstrate a sig- 
nificant ecosystem role for biological diversity (Tilman 1997) so that justification for the preservation of biodiversity as a whole, rather than the preservation of species in isolation, may be based on reasons other than purely ethical (Duarte 2000). Experimental studies have concentrated on readily measurable ecosystem functions such as accumulation of biomass or nutrient cycling, but there is an urgent need to extend studies to full ecosystems with multiple trophic levels and functional groups, including animal and microbial biodiversity (Loreau 2000).

The clarification of links between changes in species diversity and ecosystem functions and services is very relevant in marine systems, particularly coastal zones where losses of mangroves, coral reefs and seagrass beds are widespread (Fortes 1988, Short \& WyllieEcheverria 1996). Seagrass beds are particularly well suited for the examination of links between species diversity and ecosystem functions (Duarte 2000). About 50 seagrass species exist, of which no more than 12 coexist in any one community. Species are physiologically similar with similar functions and metabolic pathways, and species share a similar architecture to the extent that they may be considered to be scaled models of a single growth plan (Duarte 1991, Marbà \& Duarte 1998). Therefore, an absence of relationship between species diversity and ecosystem function is a plausible a priori null hypothesis in seagrass communities (Duarte 2000). Seagrasses occupy shallow waters along coastal fringes and are therefore highly susceptible to direct stresses imposed by man (Fortes 1988). Currently, they are experiencing worldwide decline, with substantial losses in cover (Short \& WyllieEcheverria 1996) which are often catastrophic and self-accelerating, rather than gradual, events. Studies of species erosion in relation to siltation (Duarte et al. 1997, Terrados et al. 1998) and nutrient enrichment (Fourquean et al. 1995) show that species loss is not random, as different species have differing sensitivities. The consequences of partial losses are poorly understood and there is a lack of evident effects of declining species diversity on ecosystem functions.

Seagrasses are considered to be ecosystem engineers or structural species and are known to influence their surroundings in complex and profound ways (Fonseca 1996). They alter sediment granulometry, stabilise sediments, trap detritus, influence sediment chemistry both directly and indirectly, and alter the microbial and microphytic communities within sediments. Freeliving nematodes distributions are closely linked to small changes in sediment structure, chemistry, disturbance, and potential food such as bacteria and microphytobenthos (Giere 1993). In light of these facts, we consider the nematode assemblage within a particular seagrass patch to be indicative of the pre- vailing environmental conditions within that patch, and the community structure of the nematodes to be a surrogate measure of integrated ecosystem functions. If nematode community structure varies between patches, it may be implied that the seagrasses are affecting environmental conditions differently, indicating differences in ecosystem functioning between patches without necessarily describing the exact nature of those differences.

Using this approach we address 4 main hypotheses: (1) the number of nematode species in a seagrass patch depends on the number of seagrass species in the patch; (2) the abundance of nematodes in a seagrass patch depends on the number of seagrass species in the patch; (3) the community structure of nematodes in a seagrass patch depends on the number of species of seagrasses present in the patch; and (4) the community structure of nematodes in a seagrass patch depends on the individual species of seagrasses present in the patch.

\section{MATERIALS AND METHODS}

Study sites and sample collection. This study was carried out at 2 sites on the Andaman coast of Thailand (Fig. 1), where the dominant coastal ecosystems are mangroves, coral reefs and seagrass beds. Some seagrass beds are associated with mangroves or coral reefs, but beds on shallow sandy bottoms in areas pro-

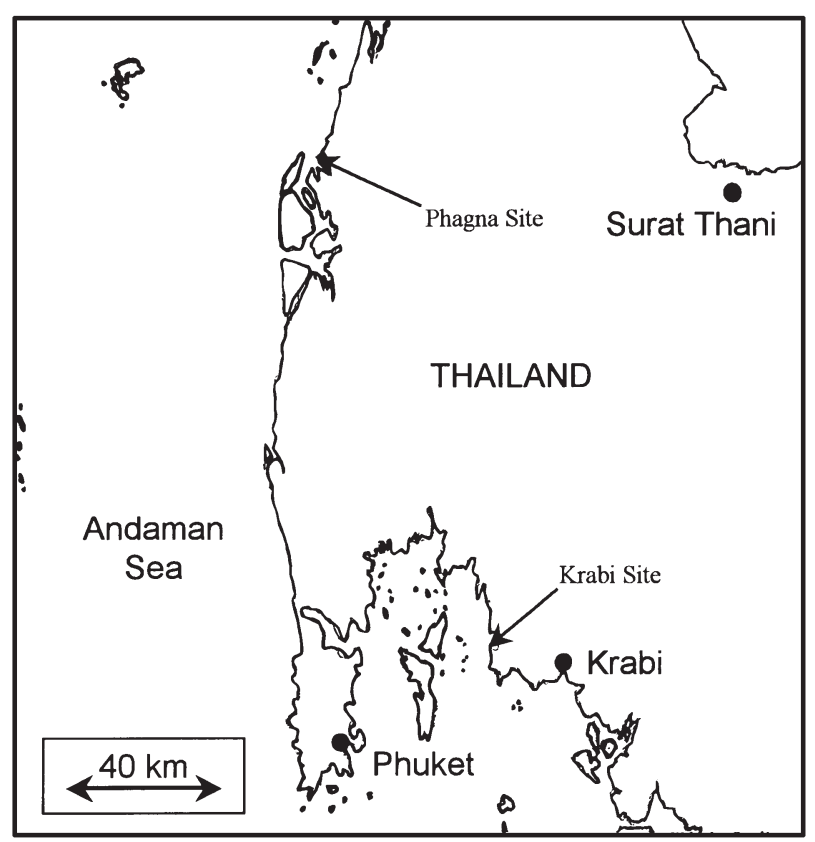

Fig. 1. Map showing the locations of the 2 sampling sites (indicated with arrows) 
tected from wave action are the most speciose, cover large areas and generally have high grass cover. Individual species of seagrasses show little zonation along transects and the most speciose beds contain mixed stands (Chansang \& Poovachiranon 1994). Two such sites were selected for this study.

The study site in Krabi province $\left(8^{\circ} 05^{\prime} \mathrm{N}, 98^{\circ} 50^{\prime} \mathrm{E}\right.$, referred to hereafter as 'Krabi') is located near Ban Tha Lens (Fig. 1). The shore consists of large expanses of tidal flats extending approximately $1 \mathrm{~km}$ seawards, and stretching some $9 \mathrm{~km}$ along the coast. The sediment consists of sand and contains large numbers of active bioturbators, particularly crustaceans and echinoderms. All over the tidal flat patches of seagrasses occur, ranging from 1 to $5 \mathrm{~m}$ in diameter. There is no clear relationship between the sizes of seagrass patches and the species of seagrass growing in them, and different patches contain different numbers and combinations of seagrass species. Species occurring on the shore are Halophila ovalis (R. Br.) Hook f., H. minor (Zoll.) den Hartog, Thalassia hemprichii (Ehrenb.) Aschers., Halodule uninervis (Forssk.) Aschers., Cymodocea serratula (R. Br.) Aschers. \& Magnus and Enhalus acoroides (L. f.) Royle. Although $H$. ovalis tends to dominate close to the shore and E. acoroides at the extreme low-water mark and in the shallow waters beyond, there is no clear evidence of zonation

Table 1. Seagrass species inhabiting patches at the 2 sites, the number of patches sampled $(\mathrm{N})$, and the groups (Species 1, 2 and 3, Treatment) into which patches were classified for subsequent analyses. Equal numbers indicate patches are grouped together

\begin{tabular}{|lcccc|}
\hline Krabi & N & Species 1 & Species 2 & Treatment \\
\hline Bare sediment & 4 & 0 & 0 & 0 \\
Enhalus acoroides & 2 & 1 & 1 & 1 \\
Thalassia hemprichii & 4 & 1 & 1 & 2 \\
Halodule uninervis & 2 & 1 & 1 & 3 \\
Halophila ovalis \& H. minor & 4 & 2 & 1 & 4 \\
E. acoroides \& T. hemprichii & 4 & 2 & 2 & 5 \\
E. acoroides \& H. ovalis \& H. minor & 4 & 3 & 2 & 6 \\
T. hemprichii \& H. ovalis \& H. minor & 4 & 3 & 2 & 7 \\
& & & & \\
Phagna & $\mathrm{N}$ & Species 1 & Species 3 & Treatment \\
\hline Bare sediment & 4 & 0 & 0 & 0 \\
Halodule pinifolia & 1 & 1 & 1 & 1 \\
H. uninervis & 2 & 1 & 1 & 2 \\
Cymodocea serratula & 3 & 1 & 1 & 3 \\
C. rotundata & 4 & 1 & 1 & 4 \\
Enhalus acoroides & 3 & 1 & 1 & 5 \\
Syringodium isoetifolium & 4 & 1 & 1 & 6 \\
H. pinifolia \& Halophila ovalis & 2 & 2 & 2 & 7 \\
S. isoetifolium \& H. ovalis & 3 & 2 & 2 & 8 \\
C. serratula \& H. ovalis & 4 & 2 & 2 & 9 \\
C. serratula \& H. pinifolia \& H. ovalis & 2 & 3 & 2 & 10 \\
C. serratula \& H. uninervis \& H. ovalis & 4 & 3 & 2 & 11 \\
& & & & \\
\hline
\end{tabular}

amongst seagrass species across most of the tidal flat and no obvious differences in location between patches of seagrasses with differing species composition.

Sampling was carried out on 1 and 2 March 1999 during low-water spring tides. Seagrass patches with varying species composition, and patches of bare sediment, were selected at random between 400 and $600 \mathrm{~m}$ from the upper shore (Table 1). Within each patch 3 cores (sawn-off $10 \mathrm{ml}$ syringe, inserted to a depth of $5 \mathrm{~cm}$ ) were collected and pooled in order to represent the fauna of the patch as a whole, and to minimise the effects of small-scale within-patch variability.

The second study site, in Phagna province $\left(9^{\circ} 15^{\prime} \mathrm{N}\right.$, $98^{\circ} 21^{\prime} \mathrm{E}$, hereafter referred to as 'Phagna'), is located near Ban Thung Nang Dam (Fig. 1). Samples were collected from a patchy mixed seagrass meadow containing Halophila ovalis, Cymodocea serrulata, Cymodocea rotundata Ehrenb. \& Hempr. ex Aschers., Syringodium isoetifolium (Aschers.) Dandy, Halodule uninervis, Halodule pinifolia (Miki) den Hartog and Enhalus acoroides. The meadow is about $2 \mathrm{~km}^{2}$, growing in slightly muddy sand and, although bioturbatory activity did not appear to be as intense as at the Krabi site, many bioturbators (predominantly echinoderms) were present. Again patches were chosen on the basis of their seagrass species composition (Table 1) and sampled, using the same methods as used at Krabi, during low water spring tides on 6 April 1999.

Faunal analysis. Samples for faunal analysis were fixed in 10\% formalin, then washed with filtered freshwater through a $63 \mu \mathrm{m}$ sieve. The residue from the $63 \mu \mathrm{m}$ sieve was separated into heavy and light fractions using decantation (Warwick et al. 1998), repeated 6 times, and the light fraction (containing the nematodes) stored in $4 \%$ formalin prior to examination. Methods used for examination followed Somerfield \& Warwick (1996). Briefly, formalin was washed from each sample on a $63 \mu \mathrm{m}$ sieve. Remaining fine sand and inorganic material was removed using flotation in colloidal silica (Ludox-TM) with a specific gravity of 1.15 and repeated 3 times. A subsample (1/5) was taken by resuspending the remaining sample in a known volume of filtered freshwater and withdrawing a known volume from it, washed into a cavity block using a mixture of $5 \%$ glycerol and $10 \%$ ethanol in filtered freshwater, 
and allowed to evaporate to pure glycerol. Finally, subsamples were spread on microscope slides and the coverslips were sealed using a paraffin wax ring and 2 coats of Bioseal prior to analysis using a differential interference phase contrast compound microscope. Nematodes were identified to putative species aided by the pictorial key of Warwick et al. (1998).

Data analyses. To address each hypothesis, a different grouping of seagrass patches into categories was required (Table 1). Combinations were made in such a way as to randomise out potential confounding factors, such as differences in abundance or biomass between different seagrass species, as much as possible. For samples from both Krabi and Phagna the primary grouping (Species 1) was according to the number of species of seagrasses (none, 1, 2 and 3 species). At Krabi, 2 of the species, Halophila ovalis and H. minor, were morphologically similar, the latter species tended to occur on the fringes of patches of the former species, and the 2 were not always easy to tell apart, so a further grouping (Species 2) was made in which Halophila species were treated as 1 species. At Phagna, all of the multispecies patches ( 2 and 3 species) contained $H$. ovalis, and this species did not occur in monospecific patches, so patches were grouped (Species 3) slightly differently (no seagrasses, 1 and $>1$ species). A further grouping of patches from both sites (Treatment) was made in which all combinations of seagrasses (Table 1) were considered separately. Finally, patches of seagrasses from each site were grouped according to the presence or absence of dominant (defined as species occurring in at least $30 \%$ of the patches sampled from a site) taxa of seagrasses, regardless of whether these occurred as monospecific stands or in combination with other species. At Krabi, the dominant taxa were Halophila species, Thalassia hemprichii and Enhalus acoroides, and at Phagna they were H. ovalis, Cymodocea species (C. serratula or $C$. rotundata) and Halodule species $(H$. pinifolia or $H$. uninervis).

A range of statistical analyses were applied to nematode abundances $(N)$ and species numbers $(S)$. Univariate data analyses (ANOVA) were carried out using standard statistical software. The power of ANOVA tests was determined a posteriori using the approximation $n>(k+1)+\sqrt{\left(\mathrm{k}^{2}+1\right)}$, where $k=(\sigma / \delta)^{2} \times\left[2+\Phi^{-1}(\mathrm{P})\right]^{2}$ (Clarke \& Green 1988), $n$ is the number of replicates in each treatment, $\sigma$ is the residual $\mathrm{SD}$ of a single response, $\delta$ is the absolute change in mean response that we wish to detect, $\Phi^{-1}$ is the inverse of the unit normal distribution function, and $\mathrm{P}$ is the probability of detecting $\delta$, i.e. the power of the test. Although a range of univariate indices derived from the species abundance data were calculated, including the ShannonWiener diversity index $H^{\prime}$, Margalef's $d$, Pielou's $J^{\prime}$ and
Simpson's dominance index $\lambda$, analyses of none of these showed relationships other than those shown by abundance and species numbers, and these analyses are not discussed further in this paper.

Nonparametric multivariate methods included ANOSIM (analysis of similarities, a multivariate analogue of ANOVA, Clarke \& Green 1988) and nonmetric multidimensional scaling (MDS), an ordination method which aims to map complex multivariate relationships in a fewer number (in this case 2) of dimensions. These analyses were carried out on inter-sample similarities calculated using the Bray-Curtis similarity measure. Analyses based on raw abundances reflect changes among numerically dominant species. A 4th-root transformation was also employed, in order to downweight the contribution from numerically dominant species to reveal changes among less dominant species. The majority of the techniques are described in Clarke \& Warwick (2001) and were implemented using PRIMER (Plymouth Routines in Multivariate Ecological Research) version 5.2 (see <www.primer-e.com> for details).

\section{RESULTS}

\section{Is the number of nematode species or the abundance of nematodes in seagrass patches independent of the number of seagrass species in the patches?}

No significant differences in nematode species numbers or abundances were found between the sample groupings (Species 1, 2 or 3) constructed to address differences between patches of seagrasses containing different numbers of species at the 2 study sites (Table 2). No significant differences at all were detected in data from the Krabi site. Differences between some groups of samples at the Phagna site (Treatment) were significant, reflecting minor changes with respect to the presence or absence of Cymodocea species. With a large number of tests, the probability that some of them will achieve $p<0.05$ by chance is high, and it is likely that we would be committing a Type I error if we were to interpret these results as ecologically meaningful. The fact that significance at the 0.05 level was not attained for most of the ANOVA tests for differences between treatments (Table 2) raises the question of power or, more specifically, of its complement, the probability of Type II error. This is the probability of failing to detect a real difference.

We determined a posteriori the power of the ANOVA tests (Table 2) and, assuming that $\mathrm{p}=0.05$ (Type I error, this is implicit in the test), the results indicate that in most cases the tests would have had no reasonable power to detect changes in mean values of $10 \%$ in nematode species numbers or abundance. If the 
changes in mean values were smaller, say in the order of $1 \%$, power would be so small as to be negligible. Doubling the numbers of replicates would not have been sufficient to improve matters. Indeed, to be sure of detecting differences in mean values as great as $10 \%$ would require replication at a scale that would make the majority of field investigations of real biodiversity effects totally unwieldy, and almost impossible if a $1 \%$ difference were to be detected (Table 2).

\section{Is the community structure of nematodes in seagrass patches independent of the number of species of seagrasses present in the patches?}

Having failed to detect relationships between the numbers of nematode species or nematode abundances in seagrass patches, and the numbers of seagrass species making up those patches, we need to turn to a more ecologically meaningful definition of biodiversity that reflects the overall structure of the communities being examined. We do this by adopting a multivariate approach, which retains information about the identities of the species involved and their relative abundances. For each site, 1-way ANOSIM tests were applied to test for differences between predefined groups of samples (Table 1). The results (Table 3, Figs. 2, 3, 4 \& 5) show that at the Krabi site there was a strong and highly significant difference between assemblages of free-living nematodes inhabiting seagrass patches containing different numbers of seagrass species. At Phagna, there was not such a strong relationship, but the relationship was significant when congeneric species of seagrasses were grouped together and patches were grouped into bare sediment, monospecific stands and multispecific stands.

In the present case, we can decide a priori that we expect certain groups of samples to be more or less similar to each other according to a predefined model. Our expectation is not simply that the community structure of nematodes is different in patches of seagrasses with differing numbers of seagrasses (as reflected in the null hypothesis tested by ANOSIM and ANOVA), but more subtly that there is an order to those differences as we have an expectation that nematode assemblages in samples from bare sediment differ more from samples from seagrass patches with many species than they do from samples from monospecific patches. We therefore phrase a new null hypothesis: Variation in the community structure of nematodes in seagrass patches is not linearly correlated with the number of species of seagrasses present in the patches.

To represent our expectation in each sample grouping (Species 1, 2 or 3), model distance matrices were constructed representing the expected pattern of similarities between samples if the null hypothesis was true. A Mantel procedure, using the Spearman rank correlation as the test statistic (Somerfield \& Gage 2000) was used to test the null hypothesis of no relationship between matrices (using the PRIMER program RELATE). The results (Table 3) show that at the Krabi site there was a strong and highly significant correlative relationship between the number of seagrasses comprising seagrass patches, and the community of free-living nematodes inhabiting those patches. At Phagna, there was not such a strong relationship, but the relationship was significant when congeneric species were grouped together and patches were 
Table 3. Summary of results from 1-way ANOSIM (Global $R, \mathrm{p}$ ) for differences between samples grouped according to the species composition of seagrass patches (see Table 1), and nonparametric Mantel tests (Spearman's $\rho, p)$ of 'no relationship' with seagrass species numbers, based on Bray-Curtis similarity in untransformed and 4th-root transformed nematode species composition

\begin{tabular}{|lrrrr|}
\hline & $R$ & $\mathrm{p}$ & $\rho$ & $\mathrm{p}$ \\
\hline Krabi & & & & \\
No transformation & & & & \\
$\quad$ Species 1 & 0.230 & 0.001 & 0.188 & 0.004 \\
$\quad$ Species 2 & 0.359 & $<0.001$ & 0.210 & 0.006 \\
$\quad$ Treatment & 0.345 & $<0.001$ & & \\
4th-root transformation & & & & \\
$\quad$ Species 1 & 0.206 & 0.003 & 0.178 & 0.007 \\
$\quad$ Species 2 & 0.311 & $<0.001$ & 0.197 & 0.007 \\
$\quad$ Treatment & 0.352 & 0.001 & & \\
Phagna & & & & \\
No transformation & & & & \\
$\quad$ Species 1 & 0.040 & 0.277 & 0.081 & 0.119 \\
$\quad$ Species 3 & 0.182 & 0.002 & 0.157 & 0.012 \\
$\quad$ Treatment & 0.564 & $<0.001$ & & \\
4th-root transformation & & & & \\
$\quad$ Species 1 & 0.065 & 0.176 & 0.113 & 0.069 \\
$\quad$ Species 3 & 0.225 & 0.001 & 0.197 & 0.003 \\
$\quad$ Treatment & 0.510 & 0.001 & & \\
\hline
\end{tabular}

grouped into bare sediment, monospecific stands and multispecific stands. Thus, we reject the null hypothesis and conclude that there are significant linear relationships between the number of seagrass species within patches and variation in the assemblages of free-living nematodes within those patches at each site.

\section{Is the community structure of nematodes in seagrass patches independent of the individual species of seagrasses present in the patches?}

This hypothesis is included to address the issue of a sampling effect (Loreau 2000). In other words, whether differences between treatments containing different seagrass species reflect the fact that more speciose treatments have a higher probability of containing 1 species which is actually solely responsible for the observed effects. Samples from each site were grouped according to the presence or absence of dominant species of seagrasses.

The univariate analyses (Table 4) generally failed to achieve significance at $p<0.05$, and the tests had low power. One 'significant' result, a difference in nematode abundance between samples

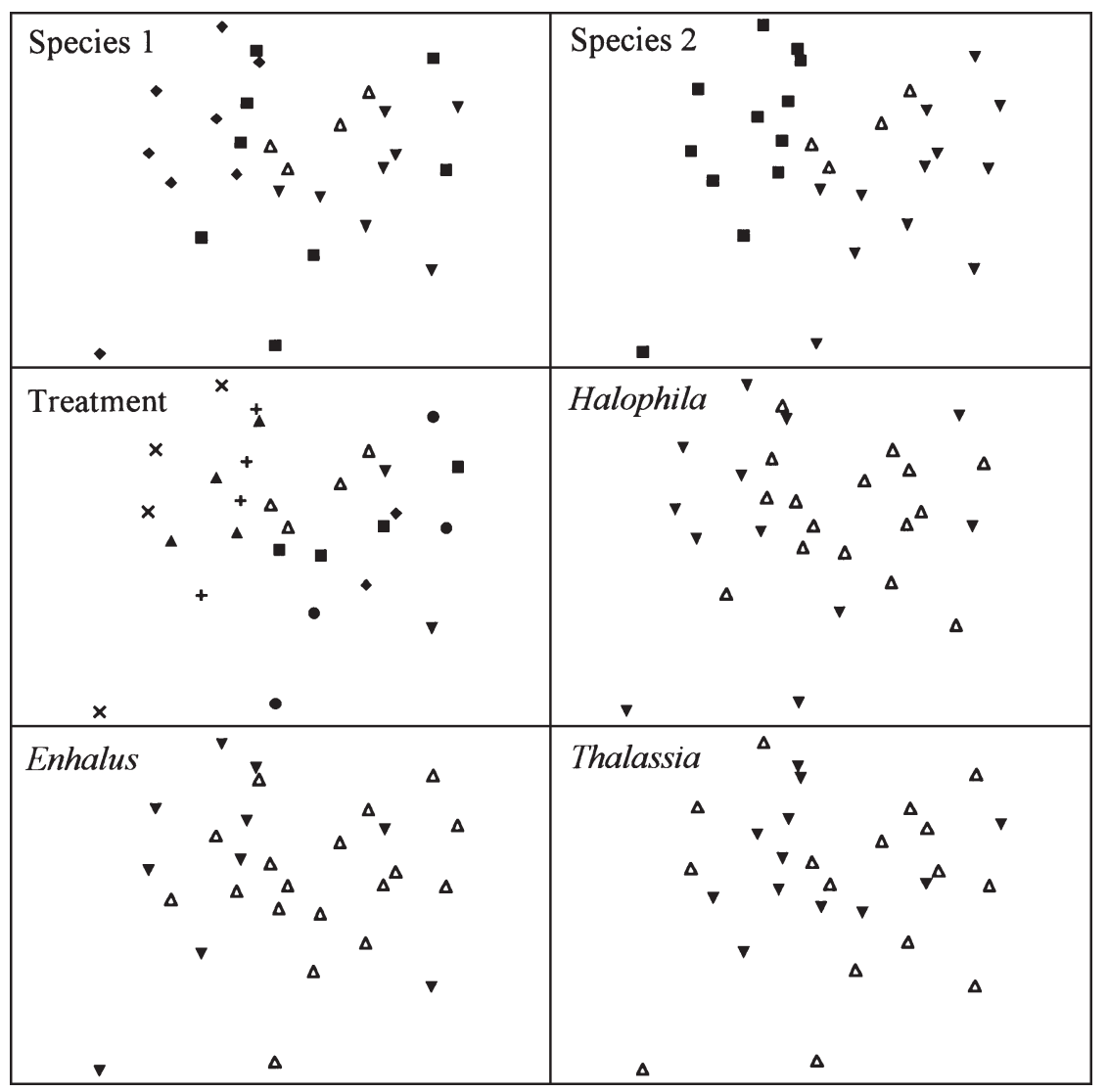

Fig. 2. Nonmetric multidimensional scaling (MDS) ordinations based on Bray-Curtis similarity of untransformed nematode abundances between samples (stress $=0.12$ ) from the Krabi site overlaid with symbols representing different groupings of seagrass patches. Species $1(\Delta$ bare sediment, $\boldsymbol{\nabla} 1$ species, $\square 2$ species, $\bullet 3$ species); Species 2 ( $\Delta$ bare sediment, $\nabla 1$ species, a 2 species); Treatment $(\Delta$ bare sediment, $\nabla$ Enhalus acoroides, - Thalassia hemprichii, • Halodule uninervis, - Halophila ovalis and $H$. minor, $+E$. acoroides and $T$. hemprichii, $\times$ E. acoroides, $H$. ovalis and $H$. minor, $\Delta ~ T$. hemprichii, $H$. ovalis and $H$. minor); Halophila; Enhalus; Thalassia ( $\mathbf{v}$ relevant taxon present, $\Delta$ relevant taxon absent) 
Fig. 3. MDS ordinations based on Bray-Curtis similarity of 4th-root transformed nematode abundances between samples (stress $=0.19$ ) from the Krabi site overlaid with symbols representing different groupings of seagrass patches. Symbols as in Fig. 2

Fig. 4. MDS ordinations based on Bray-Curtis similarity of untransformed nematode abundances between samples (stress $=0.23$ ) from the Phagna site overlaid with symbols representing different groupings of samples. Species $1(\Delta$ bare sediment, $\boldsymbol{\nabla} 1$ species, $\square 2$ species, $\bullet 3$ species); Species 3 ( $\Delta$ bare sediment, v 1 species, - 2 or more species); Treatment $(\boldsymbol{\Delta}$ bare sediment, $\mathbf{\nabla}$ Halodule pinifolia; - Halodule uninervis, - Cymodocea serratula, + Cymodocea rotundata, Enhalus acoroides, $\times$ Syringodium isoetifolium, $\triangle$ Halodule pinifolia and Halophila ovalis, $\nabla S$. isoetifolium and $H$. ovalis, $\square$ C. serratula and $H$. ovalis, $\diamond C$. serratula, $H$. pinifolia and $H$. ovalis, $\circ C$. serratula, $H$. uninervis and $H$. ovalis); Halophila; Cymodocea; Halodule ( $\mathbf{v}$ relevant taxon present, $\Delta$ relevant taxon absent)
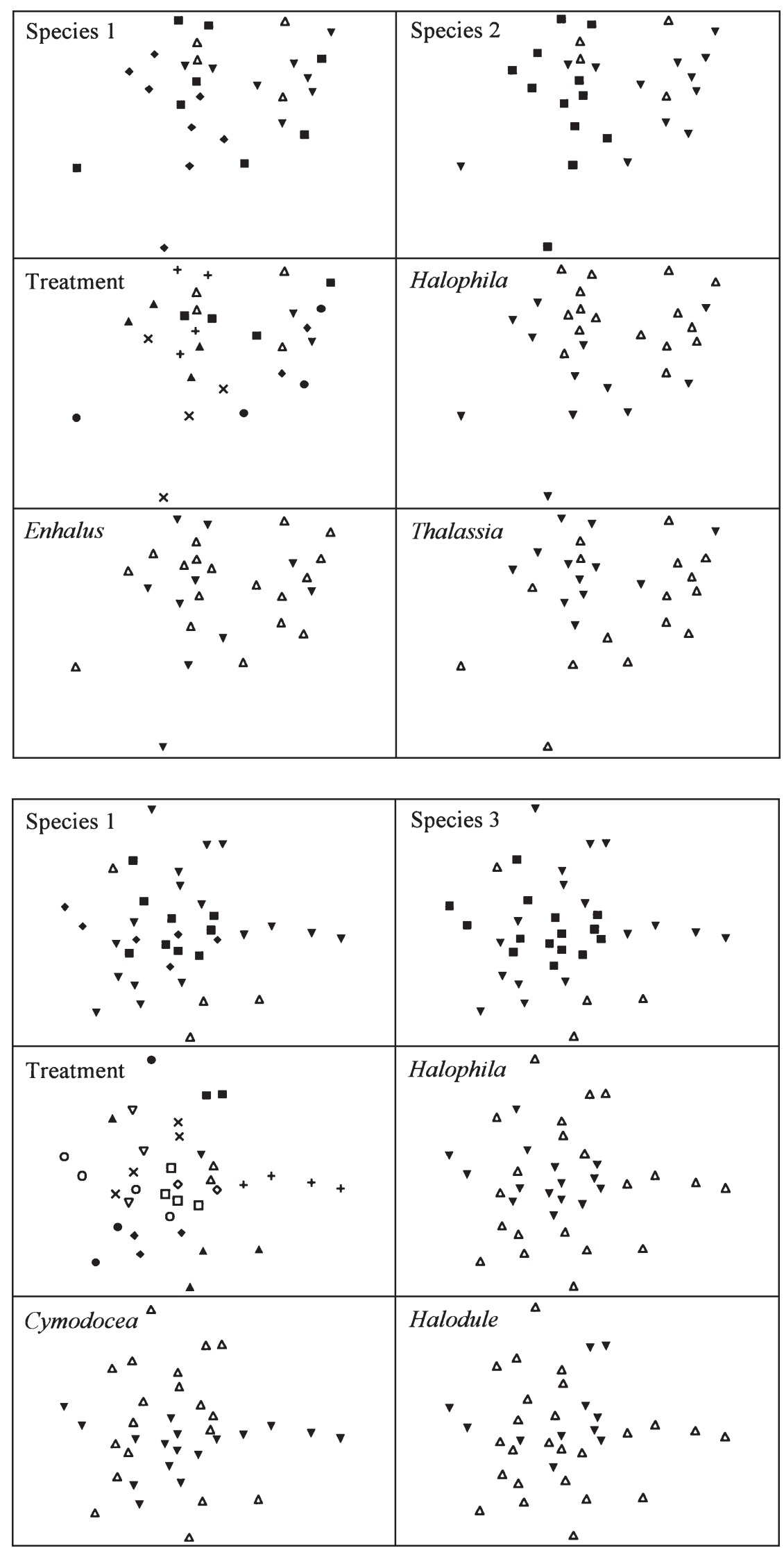


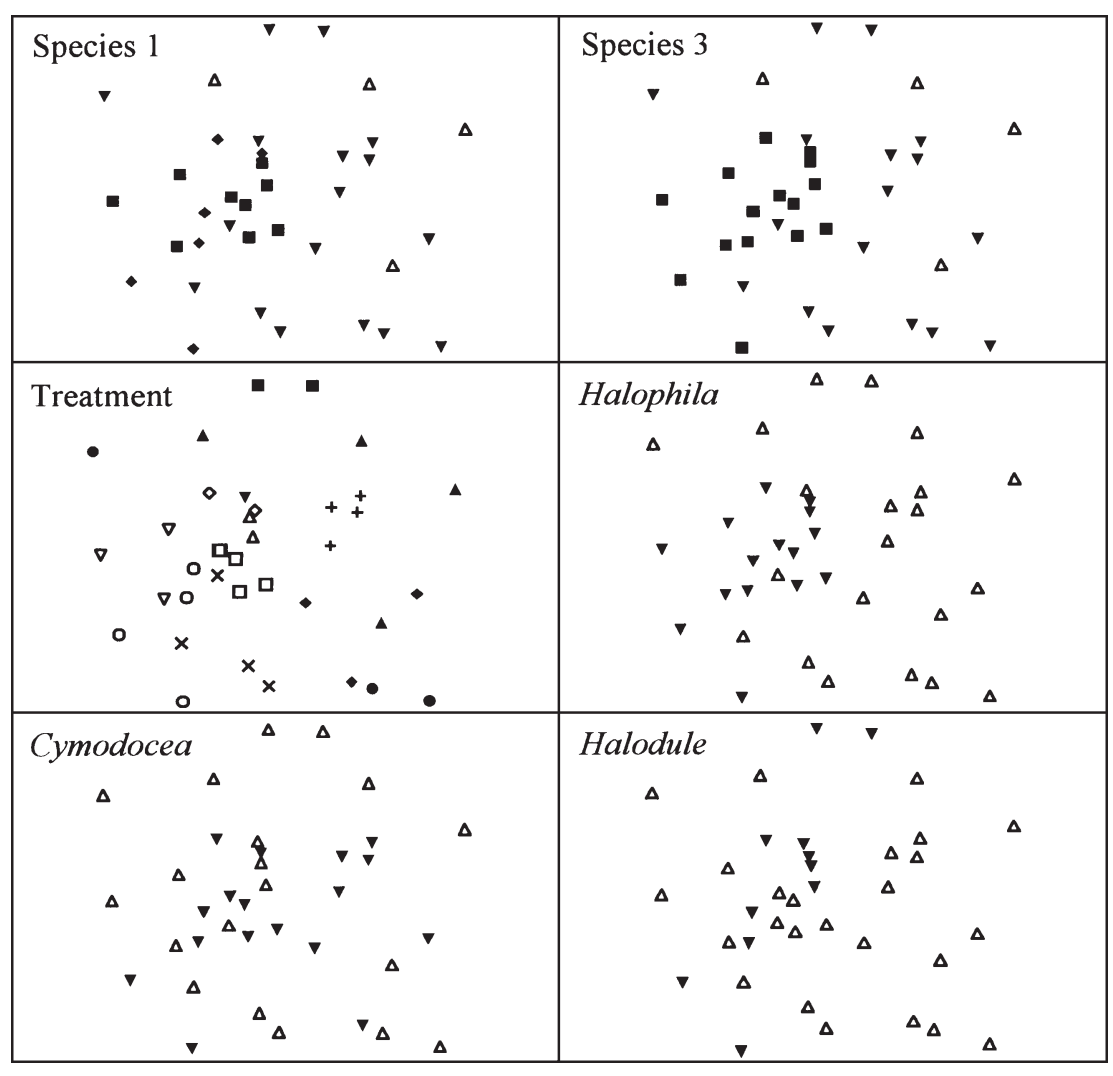

Fig. 5. MDS ordinations based on Bray-Curtis similarity of 4th-root transformed nematode abundances between samples (stress $=0.25$ ) from the Phagna site overlaid with symbols representing different groupings of seagrass patches. Symbols as in Fig. 4

containing Thalassia hemprichii from those which did not. In contrast, at the Phagna site, there were no significant differences between the nematode assemblages in samples taken from patches containing Halodule species or Cymodocea species and those that did not. Thus, we conclude that the observed relationships between the number of seagrass species in a patch and the assemblage structure of free-living nematodes within that patch are not purely a consequence of the presence or absence of a particular seagrass species. Individual species may or may not affect nematode community composition, but there is no evidence that 1 species alone is responsible for the observed relationships.

\section{DISCUSSION}

We undertook this field investigation to look for possible links between the diversity of seagrasses in multispecies tropical seagrass beds and the diversity and community structure of free-

with and without Cymodocea species at Phagna, is interpreted as a chance occurrence, and again the number of replicates required to address hypotheses relating to relationships between the presence of individual seagrass species and the abundances or numbers of species of nematodes are so high as to make such studies impracticable.

Multivariate analyses did, however, indicate significant differences between some groups of samples (Table 5). The only dominant taxon common to both sites is Halophila species. At the Krabi site, nematode assemblage structure differed significantly between samples from seagrass patches that contained Halophila, and patches that did not. At the Phagna site, nematode assemblages did not differ in terms of the dominant species present, but there were significant changes in overall species composition. It should be remembered, however, that at this site all seagrass patches containing Halophila were multispecific. At the Krabi site, there were significant differences in the dominant species inhabiting patches containing Enhalus acoroides from samples not containing the species, and a significant difference between the overall species composition in samples taken from patches living nematodes within the beds. No relationship between seagrass diversity and nematode abundance or species number was found, but a posteriori power analyses demonstrated that our sampling design had little prospect of detecting such relationships against a background of naturally occurring variability. We conclude that in a variable world biodiversity effects may be difficult to detect, even if they are large, and that great care must be taken in the design and subsequent analysis of field studies which aim to examine relationships between the biodiversity of individual taxonomic or functional groups and other aspects of ecosystems, such as the biodiversity of other taxonomic or functional components or measurements of ecosystem functioning.

Multivariate analyses showed that there is a relationship between seagrass diversity and the diversity of free-living nematodes. Different nematode assemblages occur in patches of seagrasses made up of different numbers of seagrass species, and this relationship is not determined by the presence or absence of individual seagrass species. As it is unlikely that the freeliving nematodes affect seagrass diversity, the assemblages of nematodes must be influenced either by 
Table 4. Results ( $F$ and p values from 1-way ANOVA tests) from univariate analyses of differences in nematode species number $(S)$ and abundance $(N$, ind. $2.27 \mathrm{~cm}^{-3}$ ) between seagrass patches grouped according to the presence or absence of dominant (occurring in at least $30 \%$ of samples from a site) seagrass taxa. Results of a posteriori power analyses: power of each test to detect a 10 and a $1 \%$ difference in mean values, power of each test to detect a $1 \%$ difference in mean values with twice the number of replicates, number of replicates required to detect a $1 \%$ difference with $95 \%$ power, number of replicates required to detect a $10 \%$ difference with $95 \%$ power

\begin{tabular}{|c|c|c|c|c|c|c|c|}
\hline & $F$ & $\mathrm{p}$ & $\begin{array}{l}\text { Power } \\
(10 \%)\end{array}$ & $\begin{array}{c}\text { Power } \\
(1 \%)\end{array}$ & $\begin{array}{c}\text { Power } \\
(1 \%) \text { for } 2 n\end{array}$ & $\begin{array}{c}\mathrm{n} \\
(1 \%)\end{array}$ & $\begin{array}{c}\mathrm{n} \\
(10 \%)\end{array}$ \\
\hline \multicolumn{8}{|l|}{ Krabi } \\
\hline $\begin{array}{l}\text { Halophila } \\
\text { species }\end{array}$ & $F_{1,26}$ & & & & & & \\
\hline$S$ & 1.100 & 0.304 & 0.4562 & 0.0351 & 0.0418 & 4806 & 51 \\
\hline$N$ & 0.430 & 0.518 & 0.1562 & 0.0281 & 0.0307 & 20229 & 205 \\
\hline \multicolumn{8}{|l|}{ Thalassia } \\
\hline hemprichii & $F_{1,26}$ & & & & & & \\
\hline$S$ & 0.459 & 0.504 & 0.4483 & 0.0351 & 0.0418 & 4922 & 52 \\
\hline$N$ & 1.082 & 0.308 & 0.1423 & 0.0281 & 0.0307 & 19742 & 200 \\
\hline $\begin{array}{l}\text { Enhalus } \\
\text { acoroides }\end{array}$ & \multicolumn{6}{|c|}{ Enhalus } & \\
\hline$S$ & 0.064 & 0.803 & 0.4443 & 0.0351 & 0.0418 & 4997 & 52 \\
\hline$N$ & 0.009 & 0.926 & 0.1401 & 0.0281 & 0.0307 & 20557 & 208 \\
\hline \multicolumn{8}{|l|}{ Phagna } \\
\hline \multicolumn{8}{|l|}{ Halophila } \\
\hline$S$ & 1.658 & 0.207 & 0.1075 & 0.0274 & 0.0294 & 38179 & 384 \\
\hline$N$ & 0.900 & 0.349 & 0.0455 & 0.0244 & 0.0250 & 235647 & 2359 \\
\hline $\begin{array}{l}\text { Halodule } \\
\text { species }\end{array}$ & $F_{1,34}$ & & & & & & \\
\hline$S$ & 3.624 & 0.065 & 0.1131 & 0.0274 & 0.0294 & 79133 & 798 \\
\hline$N$ & 0.210 & 0.649 & 0.0455 & 0.0244 & 0.0250 & 493800 & 4944 \\
\hline \multicolumn{6}{|l|}{ Cymodocea } & & \\
\hline$S$ & 1.822 & 0.186 & 0.1093 & 0.0274 & 0.0294 & 36184 & 364 \\
\hline$N$ & 5.147 & 0.030 & 0.0475 & 0.0244 & 0.0256 & 240399 & 2406 \\
\hline
\end{tabular}

1998), influence different species to varying extents. In SE Asian mixed seagrass meadows recolonisation is primarily vegetative (Rollon et al. 1998) and horizontal growth rate is negatively scaled to the size of the seagrass species (Duarte 1991, Vermaat et al. 1995, Marbà \& Duarte 1998) ranging by a factor of 50 across species from the slow-growing Enhalus acoroides to fast-growing species such as Halophila ovalis (Duarte 1991, Marbà \& Duarte 1998). Large slow-growing species act as climax species whereas small fast-growing species tend to be colonisers. H. ovalis, for example, colonises gaps created by the activity of burrowing shrimps (Duarte et al. 1997). Evidence of active bioturbation was seen at the sites where this study was carried out, and it is likely that this is a primary cause of the observed patchiness. Evidence of human activity (building fish traps and collecting shellfish) was also seen, and it is possible that this may have contributed to disturbance at least at the Krabi site. Thus, a range of interacting processes, but particularly bioturbation (affecting both infauna and seagrasses), contributed to the formation of the multispecific patches sampled during this study.

The processes involved in producing a mosaic of patches of seagrasses which differ in species composition,

factors which also affect seagrass diversity within patches, or by factors which vary according to the numbers of seagrass species present. Although largescale biogeographic factors influence the species pool from which species occurring within SE Asian seagrass beds are drawn (Vermaat et al. 1995), within meadows physical factors such as the prevailing hydrodynamic regime, biological factors such as interspecific differences in growth, mortality and reproduction (Fonseca 1996), and interactions between physical and biological factors (Townsend \& Fonseca 1998) influence patchiness. Interspecific competition may be a factor, although evidence suggests an absence of strong competitive interactions in the multispecific seagrass assemblages (Terrados et al. 1998, Duarte 2000, Nakaoka \& Iizumi, 2000). Disturbance (Duarte 2000), especially bioturbation (Short \& Wyllie-Echeverria 1996) and differential responses to adverse environmental conditions (Vermaat et al. 1997, Terrados et al. and therefore in the relative balance of small and large species, are likely to take effect over timescales of months to years (Rollon et al. 1998). They also alter the above- and/or belowground environment for associated invertebrates, producing varying successional patterns in space and time (Thrush et al. 1998). Nematodes react quickly to changes in environmental conditions, and we consider it less likely that the processes causing seagrass patchiness affect nematode assemblage structure directly than that this is affected by changes in environmental conditions within the seagrass patches. The majority of studies of meiofauna in seagrass systems have focussed on animals inhabiting the canopy, such as copepods (Bell et al. 1984), where effects of epibenthic structure (both natural and artificial vegetation) have been related to meiofaunal behaviour and colonisation (Palmer 1986, 1988, Cummings \& Ruber 1987, Hicks 1989, Bell \& Hicks 1991, Walters \& Bell 1994, Guerrini et al. 1998). Few studies 
Table 5. Summary of results from 1-way ANOSIM (Global $R$, p) for differences between samples grouped according to the presence or absence of dominant (occurring in at least $30 \%$ of samples from a site) seagrass taxa

\begin{tabular}{|lcc|}
\hline & $R$ & $\mathrm{p}$ \\
\hline Krabi & & \\
No transformation & & \\
$\quad$ Halophila species & 0.255 & 0.002 \\
$\quad$ Thalassia hemprichii & 0.085 & 0.071 \\
$\quad$ Enhalus acoroides & 0.135 & 0.049 \\
4th-root transformation & & \\
Halophila species & 0.219 & 0.003 \\
T. hemprichii & 0.125 & 0.027 \\
E. acoroides & 0.074 & 0.186 \\
& & \\
Phagna & & \\
No transformation & & \\
Halophila ovalis & 0.040 & 0.158 \\
Halodule species & 0.010 & 0.395 \\
Cymodocea species & 0.051 & 0.085 \\
4th-root transformation & & \\
H. ovalis & 0.082 & 0.041 \\
Halodule species & -0.014 & 0.538 \\
Cymodocea species & 0.019 & 0.283 \\
\hline
\end{tabular}

have examined infaunal meiofaunal communities, particularly in tropical seagrass systems (Ansari \& Parulekar 1994, Boucher 1997, Ndaro \& Ólafsson 1999). The overall conclusion from these studies is that nematode community structure is determined by small-scale processes that influence food availability, environmental heterogeneity (or habitat complexity) and sediment structure. Studies from non-tropical seagrass systems which mention nematodes show a similar pattern (Phillips \& Fleeger 1985, Castel et al. 1989, Danovaro 1996, Webster at al. 1998, Boström \& Bonsdorff 2000).

Seagrass species of different sizes tend to exploit different reservoirs of the same resources, and the rhizosphere of mixed meadows is partially segregated, with small and large species utilising shallower and deeper layers of the sediment, respectively (Duarte 2000). Root-rhizomes and leaves provide horizontal and vertical structural complexity, but Heck \& Wetstone (1977) found that plant species number was not significantly related to either invertebrate species number or abundance, and therefore did not appear to adequately represent habitat complexity for the invertebrate species being considered. Roots and rhizomes may also exclude certain types of infauna such as large burrowers from residing within beds, thus altering the degree of bioturbation (Brenchley 1982) or predation (Nelson 1979) to which infaunal communities are exposed. However, in a temperate Zostera marina bed it was found that large epibenthic predators and disturbers have little impact on the abundance or species composition of harpacticoid copepods (Webb \& Parsons 1991).
Sediment particle size is an important factor governing infaunal species, and therefore the ability of seagrasses to change the sedimentary environment by baffling currents and wave-action can potentially affect the composition of the infauna (Boström \& Bonsdorff 2000). Edgar (1999) found that nematodes were negatively affected by a reduction in quantity of fine organic particles amongst sediment, and that the number of species, abundance, biomass and productivity of macrofauna were overwhelmingly influenced by the addition of surface debris. The presence of artificial seagrass blades, however, produced little response implying that invertebrate communities are primarily structured by food availability with little direct dependence on the structural characteristics of seagrass beds.

The majority of the free-living nematodes found in this study were deposit, bacterial or epistrate (diatom) feeders, and seagrasses alter the availability of food for these in a number of ways. Accumulation of nutrients and carbon in seagrass-vegetated sediment is caused by plant biomass production within the meadow, of which a part is mineralised within the bed by defoliation, fractionation and breakdown of leaves (Harrison \& Mann 1975), increased sedimentation and decreased resuspension within the seagrass bed (Boström \& Bonsdorff 2000) and through the release of dissolved substances (Penhale \& Smith 1977). Freeliving nematodes within the sediment are likely to be influenced by processes involving the root-rhizome complex. The production of roots and rhizomes is often comparable to leaf production (Abal et al. 1994, Duarte et al. 1998) and 8 to $18 \%$ of the carbon fixed by a seagrass may be released to the sediments by the root-rhizomes and transferred to sediment microbial biomass within $6 \mathrm{~h}$ (Moriarty et al. 1986). The root system facilitates the exchange of gasses between the superficial sediment and deeper levels (Castel et al. 1989), potentially altering microbial communities. Leakage of photosynthates from root-rhizomes affects sediment microbial processes, stimulating nitrogen fixation, sulphate reduction, urea turnover and bacterial growth in the rhizosphere (Moriarty \& Pollard 1982, Pollard \& Moriarty 1991, Blackburn et al. 1994, Welsh et al. 1996, Blaabjerg et al. 1998, McGlathery et al. 1998, Donnelly \& Herbert 1999, Hansen et al. 2000). Living seagrass blades lie in the sediment when the tide is out and provide the benthos with an important source of epiphytic micro-organisms (Castel et al 1989). In a Mediterranean Posidonia oceanica bed, $25 \%$ of the biopolymeric fraction of sedimentary organic matter (measured as lipids, carbohydrates and proteins) was of microphytobenthic origin (Danovaro 1996). Additionally, the sandy sediments beneath Halodule wrightii beds in the USA support a diverse and productive 
benthic microalgal assemblage responsible for $23 \%$ of benthic annual production (Daehnick et al. 1992). Thus, it is likely that different mixtures of seagrass species alter environmental conditions and food availability within the sediment through a range of processes (ranging from sediment trapping to interspecific differences in photosynthate production), leading to differences in nematode community structure in seagrass patches which contain different numbers of seagrass species. In other words, seagrass biodiversity primarily determines nematode biodiversity through indirect pathways.

Two major types of mechanisms by which biodiversity influences ecosystem processes have been recognised, leading to 2 types of biodiversity effects: (1) selection of extreme trait values (the selection effect) in which trait variation is an initial condition; selection then promotes dominance by species with particular trait values; and (2) functional niche complementarity (the complementarity effect), where trait variation forms the basis for an association of species that enhances collective performance (Loreau 2000). The number of seagrass species present within patches are maintained by selection effects (Duarte 2000), evidenced by the mosaic of different species with differing capacities to withstand disturbance ensuring that bare sediments are rapidly recolonised by seagrasses and that, given time, the range of ecosystem services provided by seagrasses is maintained.

In mixed seagrass beds, a complementarity effect is evidenced by the partitioning of resources amongst species of different sizes, promoting their efficient use while reducing interspecific competition (Duarte 2000). In this study, we show that complementarity effects may also be of relevance to studies which aim to determine links between different components of ecosystems, as the free-living nematode communities inhabiting seagrass patches differ according to the number of seagrass species present. The majority of previous studies linking biodiversity to ecosystem function have focused on easily measured end-points, such as community respiration or biomass accumulation. If one accepts that the structure of a free-living nematode assemblage gives an indication of integrated ecosystem functioning, then this study also provides an alternative demonstration that ecosystem functioning within multispecific seagrass patches differs according to the number of species present, reflecting the complementarity effect. The major conclusion of this study is, therefore, that biodiversity effects do exist in the real world, but that they may be difficult to detect amongst naturally occurring background variability, especially given the complexity of natural systems comprised of interacting components.
Acknowledgements. This work was funded in part by the UK Department of the Environment's Darwin Initiative for the Survival of Species, and is a contribution to the Plymouth Marine Laboratory's research programme 'Scaling Biodiversity and the Consequences of Change' and to the research programme of the Kasetsart University Marine Coastal Resource Station. We thank all those who assisted with the field programme, especially Yaoluk Monthum.

\section{LITERATURE CITED}

Abal EG, Loneragan N, Bowen P, Perry CJ, Udy JW, Dennison WC (1994) Physiological and morphological responses of the seagrass Zostera Capricorni Aschers. to light intensity. J Exp Mar Biol Ecol 178:113-129

Ansari ZA, Parulekar AH (1994) Meiobenthos in the sediments of seagrass meadows of Lakshadweep atolls, Arabian Sea. Vie Milieu 44:185-190

Bell SS, Hicks GRF (1991) Marine landscapes and faunal recruitment: a field test with seagrasses and copepods. Mar Ecol Prog Ser 73:61-68

Bell SS, Walters K, Kern JC (1984) Meiofauna from seagrass habitiats: a review and prospectus for future research. Estuaries 7:331-338

Blaabjerg V, Mouritsen KN, Finster K (1998) Diel cycles of sulphate reduction rates in sediments of a Zostera marina bed (Denmark). Aquat Micob Ecol 15:97-102

Blackburn TH, Nedwell DB, Wiebe WJ (1994) Active mineral cycling in a Jamaican seagrass sediment. Mar Ecol Prog Ser 110:233-239

Boström C, Bonsdorff E (2000) Zoobenthic community establishment and habitat complexity-the importance of shoot-density, morphology and physical disturbance for faunal recruitment. Mar Ecol Prog Ser 205:123-138

Boucher G (1997) Structure and biodiversity of nematode assemblages in the SW lagoon of New Caledonia. Coral Reefs 16:177-186

Brenchley GA (1982) Mechanisms of spatial competition in marine soft-sediment communities. J Exp Mar Biol Ecol 60:17-33

Cardinale BJ, Nelson KN, Palmer MA (2000) Linking species diversity to the functioning of ecosystems: on the importance of environmental context. Oikos 91:175-183

Castel J, Labourg P, Escaravage V, Auby I, Garcia ME (1989) Influence of seagrass beds and oyster parks on the abundance and biomass of meio- and macrobenthos in tidal flats. Estuar Coast Shelf Sci 28:71-85

Chansang H, Poovachiranon S (1994) The distribution and species composition of seagrass beds along the Andaman Sea coast of Thailand. Phuket Mar Biol Cent Res Bull 59: $43-52$

Clarke KR, Green RH (1988) Statistical design and analysis for a 'biological effects' study. Mar Ecol Prog Ser 46: 213-226

Clarke KR, Warwick RM (2001) Changes in marine communities: an approach to statistical analysis and interpretation, 2nd edn. Primer-e, Plymouth

Cummings E, Ruber E (1987) Copepod colonisation of natural and artificial substrates in a salt marsh pool. Estuar Coast Shelf Sci 25:637-645

Daehnick AE, Sullivan MJ, Moncreiff CA (1992) Primary production of the sand microflora in seagrass beds of Mississippi Sound. Bot Mar 35:131-139

Danovaro R (1996) Detritus-bacteria-meiofauna interactions in a seagrass bed (Posidonia oceanica) of the NW Mediterranean. Mar Biol 127:1-13 
Donnelly AP, Herbert RA (1999) Bacterial interactions in the rhizosphere of seagrass communities in shallow coastal lagoons. J Appl Microbiol 85:151-160

Duarte CM (1991) Allometric scaling of seagrass form and productivity. Mar Ecol Prog Ser 77:289-300

Duarte CM (2000) Marine biodiversity and ecosystem services: an elusive link. J Exp Mar Biol Ecol 250:117-131

Duarte CM, Terrados J, Agawin NSR, Fortes MD, Bach S, Kenworthy WJ (1997) Response of a mixed Philippine seagrass meadow to experimental burial. Mar Ecol Prog Ser 147:285-294

Duarte CM, Merino M, Agawin NSR, Uri J, Fortes MD, Gallegos ME, Marbà M, Hemminga MA (1998) Root production and belowground seagrass biomass. Mar Ecol Prog Ser 171:97-108

Edgar GJ (1999) Experimental analysis of structural versus trophic importance of seagrass beds. I. Effects on macrofaunal and meiofaunal invertebrates. Vie Milieu 49: $239-248$

Emmerson MC, Solan M, Emes C, Paterson DM, Rafaelli D (2001) Consistent patterns and the idiosyncratic effects of biodiversity in marine ecosystems. Nature 411:73-77

Engelhardt KAM, Ritchie ME (2001) Effects of macrophyte species richness on wetland ecosystem functioning and services. Nature 411:687-689

Fonseca MS (1996) The role of seagrasses in nearshore sedimentary processes: a review. In: Nordstrom KF, Roman CT (eds) Estuarine shores: evolution, environments and human alterations. Wiley Scientific Publishers, Chichester, p 261-286

Fortes MD (1988) Mangrove and seagrass beds of East Asia: habitats under stress. Ambio 17:207-213

Fourqurean JW, Powell GVN, Kenworthy WJ, Zieman JC (1995) The effects of longterm manipulation of nutrient supply on competition between the seagrasses Thalassia testudinum and Halodule wrightii in Florida Bay. Oikos 72:349-358

Giere O (1993) Meiobenthology: the microscopic fauna in aquatic sediments. Springer-Verlag, Berlin

Guerrini A, Colangelo MA, Ceccherelli VU (1998) Recolonisation patterns of meiobenthic communities in brackish vegetated and unvegetated habitats after induced hypoxia/ anoxia. Hydrobiologia 375:73-87

Hansen JW, Udy JW, Perry CJ, Dennison WC, Lomstein BA (2000) Effect of the seagrass Zostera capricorni on sediment microbial processes. Mar Ecol Prog Ser 199:83-96

Harrison PG, Mann KH (1975) Detritus formation from eelgrass Zostera marina (L.): the relative effects of fragmentation, leaching and decay. Limnol Oceanogr 20:924-934

Heck KL Jr, Wetstone GS (1977) Habitat complexity and invertebrate species richness and abundance in tropical seagrass meadows. J Biogeogr 4:135-142

Heip C, Warwick R, d'Ozouville L (1998) A European science plan on marine biodiversity. European Science Foundation, Strasbourg

Hicks GRF (1989) Does epibenthic structure negatively affect meiofauna? J Exp Mar Biol Ecol 133:39-55

Loreau M (2000) Biodiversity and ecosystem functioning: recent theoretical advances. Oikos 91:3-17

Marbà N, Duarte CM (1998) Rhizome elongation and seagrass clonal growth. Mar Ecol Prog Ser 174:269-280

McGlathery KJ, Risgaard-Petersen N, Christensen PB (1998) Temporal and spatial variation in nitrogen fixation activity in the eelgrass Zostera marina rhizosphere. Mar Ecol Prog Ser 168:245-258

Moriarty DJW, Pollard PC (1982) Diel variation of bacterial productivity in seagrass (Zostera capricorni) beds, mea- sured by rate of thymidine incorporation into DNA. Mar Biol 72:165-173

Moriarty DJW, Iverson RL, Pollard PC (1986) Exudation of organic carbon by the seagrass Halodule wrightii Aschers. and its effect on bacterial growth in the sediment. J Exp Mar Biol Ecol 96:115-126

Naeem S, Thompson LJ, Lawler SP, Lawton JH, Woodfin RM (1994) Declining biodiversity can alter the performance of ecosystems. Nature 368:734-737

Nakaoka M, Iizumi H (2000) Magnitude of within-patch variation in seagrass Halophila ovalis growth affected by adjacent Thalassia hemprichii vegetation. Ecol Res 15: 415-424

Ndaro SGM, Ólafsson E (1999) Soft-bottom fauna with emphasis on nematode assemblage structure in a tropical intertidal lagoon in Zanzibar, eastern Africa. I. Spatial variability. Hydrobiologia 405:133-148

Nelson WG (1979) An analysis of structural patterns in an eelgrass (Zostera marina L.) amphipod community. J Exp Mar Biol Ecol 39:231-264

Palmer MA (1986) Hydrodynamics and structure: interactive effects on meiofauna dispersal. J Exp Mar Biol Ecol 104: 53-68

Palmer MA (1988) Dispersal of marine meiofauna: a review and conceptual model explaining passive transport and active emergence with implications for recruitment. Mar Ecol Prog Ser 48:81-91

Penhale PA, Smith WO Jr (1977) Excretion of dissolved organic carbon by eelgrass (Zostera marina [L.]) and its epiphytes. Limnol Oceanogr 22:400-407

Phillips SE, Fleeger JW (1985) Meiofauna meso-scale variability in estuarine habitats. Estuar Coast Shelf Sci 21: 745-756

Pollard PC, Moriarty DJW (1991) Organic carbon decomposition, primary and bacterial productivity, and sulfate reduction, in tropical seagrass beds of the Gulf of Carpentaria, Australia. Mar Ecol Prog Ser 69:149-159

Rollon RN, Van Steveninck EDD, Van Vierssen W, Fortes MD (1998) Contrasting recolonization strategies in multispecies seagrass meadows. Mar Pollut Bull 37:450-459

Schläpfer F, Schmid B, Seidl I (1999) Expert estimates about effects of biodiversity on ecosystem processes and services. Oikos 84:346-352

Short FT, Wyllie-Echeverria S (1996) Natural and humaninduced disturbance of seagrasses. Environ Cons 23: $17-27$

Somerfield PJ, Gage JD (2000) Community structure of the benthos in Scottish sea-lochs. IV. Multivariate spatial pattern. Mar Biol 136:1133-1145

Somerfield PJ, Warwick RM (1996) Meiofauna in marine pollution monitoring programmes: a laboratory manual. MAFF Directorate of Fisheries Research Technical Series, Lowestoft

Terrados J, Duarte CM, Fortes MD, Borum J and 7 others (1998) Changes in community structure and biomass of seagrass communities along gradients of siltation in SE Asia. Estuar Coast Shelf Sci 46:757-768

Thrush SF, Lawrie SA, Hewitt JE, Cummings VJ (1998) The problem of scale: uncertainties and implications for soft-bottom communities and the assessment of human impacts. In: Gray JS, Ambrose W Jr, Szaniawska A (eds) Biogeochemical cycling and sediment ecology. Kluwer Academic Publishers, Dordrecht, p 195-210

Tilman D (1997) Distinguishing the effects of species diversity and species composition. Oikos 80:185

Tilman D, Downing JA (1994) Biodiversity and stability in grasslands. Nature 367:363-365 
Tilman D, Wedin D, Knops J (1996) Productivity and sustainability influenced by biodiversity in grassland ecosystems. Nature 379:718-720

Townsend EC, Fonseca MS (1998) Bioturbation as a potential mechanism influencing spatial heterogeneity of North Carolina seagrass beds. Mar Ecol Prog Ser 169:123-132 Vermaat JE, Agawin NSR, Duarte CM, Fortes MD, Marbà N, Uri JS (1995) Meadow maintenance, growth and productivity of a mixed Philippine seagrass bed. Mar Ecol Prog Ser 124:215-225

Vermaat JE, Agawin NSR, Duarte CM, Enríquez S, Fortes MD, Marbà N, Uri JS, van Vierssen W (1997) The capacity of seagrasses to survive increased turbidity and siltation: the significance of groth form and light use. Ambio 26:499-504

Walters K, Bell SS (1994) Significance of copepod emergence to benthic, pelagic and phytal linkages in a sublittoral seagrass bed. Mar Ecol Prog Ser 108:237-249

Editorial responsibility: Otto Kinne (Editor),

Oldendorf/Luhe, Germany
Warwick RM, Platt HM, Somerfield PJ (1998) Freeliving marine nematodes. Part III. Monhysterids. Synopses of the British fauna (New Series) No. 53. Field Studies Council, Shrewsbury

Webb DG, Parsons TR (1991) Inpact of predation-disturbance by large epifauna on sediment dwelling harpacticoid copepods: field experiments in a subtidal seagrass bed. Mar Biol 109:485-491

Webster PJ, Rowden AA, Attrill MJ (1998) Effect of shoot density on the infaunal macro-invertebrate community within a Zostera marina seagrass bed. Estuar Coast Shelf Sci 47:351-357

Welsh DT, Bourguès S, de Wit R, Herbert RA (1996) Seasonal variations in nitrogen-fixation (acetylene reduction) and sulfate-reduction rates in the rhizosphere of Zostera noltii: nitrogen fixation by sulfate-reducing bacteria. Mar Biol $125: 619-628$

Submitted: July 20, 2001; Accepted: February 26, 2002 Proofs received from author(s): June 24, 2002 